\title{
The Patient Griselda Myth and Marriage Anxieties on Early Modern English and Spanish Stages
}

The Patient Griselda myth tells the story of a marquis who is reluctant to get married, but, under pressure from his subjects, agrees to take a wife and chooses a poor young country girl for her virtues. Once married, he doubts his wife's perfection and therefore tests her for more than ten years by taking away her children, pretending to have them killed, and by repudiating her. Finally, the marquis asks her to prepare his second wedding with a young noble lady. This second wedding never occurs, since the marquis finally reveals that the bride and her brother are Griselda's children; what is actually celebrated is the family reunion and Griselda's patience. This tale, which to our modern perceptions may appear horrible, fascinated Europe from the late fourteenth century until the nineteenth century, as the many translations and adaptations it underwent attest. ${ }^{1}$

I consider the Patient Griselda narrative an early modern European myth both in the specific Aristotelian sense of mythos, i.e., a story of some length that is easily remembered, with a beginning, middle and end, which can be used as a plot or argument for drama, and the more general meaning of a story belonging to a wider network of stories constituting the mythology of a given culture at a certain point in time. I here follow William G. Doty's definition of mythology:

\begin{abstract}
A mythological corpus consists of (1) a usually complex network of myths that are (2) culturally important, (3) imaginal (4) stories, conveying by means of (5) metaphoric and symbolic diction, (6) graphic imagery, and (7) emotional conviction and participation (8) the primal, foundational accounts (9) of aspects of the real, experienced world and (10) humankind's roles and relative statuses within it.

Mythologies may (11) convey the political and moral values of a culture and (12) provide systems of interpreting (13) individual experience within a universal perspective, which may include (14) the intervention of suprahuman entities as well as (15) aspects of the natural and cultural orders. Myths may be enacted or reflected in (16) rituals, ceremonies, and dramas, and (17) they may provide materials for secondary elaboration, the constituent
\end{abstract}

1 There are later adaptations, the most recent I am aware of being an American sequel presenting Griselda's daughter about to get married and trying to make sense of her mother's life-story (Tinney Sue Heath, The Patience of Griselda [e-book: Callihoo Publishing, 2011]). However, the tale has today clearly lost its previously enormous appeal. 
mythemes (mythic units) having become merely images or reference points for a subsequent story, such as a folktale, historical legend, novella, or prophecy. ${ }^{2}$

I do not here have enough room for a thorough analysis of how the Patient Griselda story fits these criteria-and some obviously do not apply, such as number (8), "primal and foundational accounts"-but I will briefly demonstrate that most of these features can be identified when considering the artistic life of the story from its first known occurrence in the Italian Renaissance to the early modern period. ${ }^{3}$

Although it may not yet have functioned or been recognised as a myth when it initially appeared in Italy as the last novella of Giovanni Boccaccio's Decameron (written around 1353), its subsequent literary-oral and written-and iconographic life $\mathrm{e}^{4}$ gradually enabled the mythification of the Patient Griselda story at the European level. ${ }^{5}$

2 William G. Doty, Mythography: The Study of Myths and Rituals, 2nd ed. (Tuscaloosa, AL: University of Alabama Press, 2000), pp. $33 \mathrm{f}$.

3 For Doty, a myth does not need to meet all the above criteria, but a "sufficient number of common features among those of the definition to be recognisable as 'myth'" (Mythography, p. 33).

4 For an analysis of the figure of Griselda in select representations in the pictorial arts see Judith Bronfman, Chaucer's Clerk's Tale: The Griselda Story Received, Rewritten, Illustrated (New York, NY/London: Garland Publishing, 1994), esp. chap. 5, pp. 93-124.

5 Igor Candido links Boccaccio's novella with the myth of Psyche and Eros: "Boccaccio costruisce [...] il personaggio di Griselda su quello di Psiche, perfezionando il suo modello da un punto di vista morale. [...] il confronto tra Griselda e Psiche implica in chiave allegorica il superamento della seconda da parte della prima" [Boccaccio constructs [...] the character of Griselda on that of Psyche, perfecting his model from a moral point of view [...] the comparison between Griselda and Psyche implies in allegorical terms that the former surpasses the latter] (Igor Candido, "Amore e Psiche dalle chiose del Laur. 29.2 alle due redazioni delle Genealogie e ancora in Dec. X, 10,” Studi sul Boccaccio 37 (2009), pp. 171-196, p. 195; my translation). He concludes that "[r]iscritta nella novella di Griselda, la fabula di Amore e Psiche assolveva alla stessa funzione che aveva nel suo contesto originale, consolare le donne ristrette dai voleri di padri, fratelli e mariti, tutti gli uomini segnati dall'esperienza della peste, ma nell'exemplum di una donna [...] Boccaccio [...] additava, alla fine del suo capolavoro, l'ideale di perfezione raggiungibile dall'anima umana" [rewritten in Griselda's novella, the fabula of Love and Psyche assumes the same function it had in its original context: comfort women restrained by the wills of fathers, brothers and husbands, all the men scarred by the experience of the plague, but in the exemplum of a woman [...] Boccaccio points out at the end of his masterpiece the ideal of perfection that a human soul can reach] (Candido, "Amore e Psiche," p. 196; my translation). Although Marina Warner rightly stresses that "[e]very telling of a myth is part of that myth: there is no ur-version, no authentic prototype, no true account” (Marina Warner, Six Myths of Our Time: Little Angels, Little Monsters, Beautiful Beasts, and More [New York, NY: Vintage Books, 1995], p. 13), I treat Boccaccio's text not as a myth but as the starting point from which Psyche and Eros's myth was reshaped to suit European-Christian culture and ideology-in other words mythology; and the novella would have to undergo a hundred and 
From its original claimed purpose of representing a "matta bestialità"6 or "foolish cruelty," according to Dioneo, the novella's narrator, it became an edifying tale of the perfect Christian under Petrarch's pen in his 1373 Latin translation, “De obedentia [sic!] et fide uxoria” (Seniles, 17, 3). Since Petrarch's version, not only did the Italian story gain popularity at the European level, as the translations into many vernacular languages attest, but artists also started to represent some scenes from the story in paintings. In addition, probably under the influence of the title Petrarch gave the story, many of the literary and pictorial realisations of the tale were associated with wedding celebrations or marital life. The Catalan Bernat Metge dedicated his Valter e Griselda (1388) to Isabel de Guimerà with the hope of strengthening her already virtuous behaviour as a wife. The French Philippe de Mézière is the author of Le Livre de la vertu du sacrement de mariage et $d u$ reconfort des dames mariees (c. 1384-1389), which contains among other exemplary stories that of Griselda, and whose title makes explicit the didactic purpose of this collection of tales in relation to marriage. Mézière is also thought to have composed the first theatrical adaptation of the story, L'Estoire de Griseldis (1395), which may have been written to promote a marriage between Richard II of England and the French Isabella of Valois, given Mézière's implication in the match, and the fact that his richly illustrated manuscript provides nineteen pictorial representations of several scenes from the story. ${ }^{7}$ In fifteenth-century Italy, common wedding gifts were cassoni or wooden chests decorated with paintings, which in the 1480s and 1490s frequently represented Griselda. ${ }^{8}$ The anonymous Spanish "treatise" (as the author calls it), Castigos y doctrinas que un sabio daba a sus hijas, written in the fifteenth century, also uses the story of Griselda as an exemplum of wifely behaviour. La historia de Griseldis Marquesa de Saluces: a exemplo de las dueñas casadas: prouocandolas a obediencia paciencia y constancia y a toda virtud (anonymous, printed in 1544), as its title indicates, is addressed to wives and aims to teach them "obedience, patience and constancy and all virtues.”

These are a few examples. During the fifteenth and the sixteenth centuries more adaptations and pictorial reproductions appeared not only in England,

fifty years of rewritings, translations, adaptations and iconographic representations to become, from an Italian story, an early modern European myth.

6 Giovanni Boccaccio, Decameron [1353], ed. Vittore Branca, 2 vols. (Torino: Einaudi, 1992), vol. 2, p. 1233.

7 See L'Estoire de Griseldis [1395], ed. Barbara Mary Craig (Lawrence, KS: University of Kansas Publications, 1954), pp. $4 \mathrm{f}$.

8 See Ellen Callmann, "The Growing Threat to Marital Bliss as seen in Fifteenth-Century Florentine Paintings,” Studies in Iconography 5 (1979), pp. 73-92. 
France, Spain and Italy, but all across Europe. These numerous rewritings, ${ }^{9}$ and the fact that the simple mention of Griselda's name in any of its spellings (Grissild, Grissel, Griseldis, etc.) sufficed to evoke her story and her exemplarity, attest to the cultural importance of the story. ${ }^{10}$ The above-mentioned examples of the story's artistic realisations being linked with marriage show that not only is it grounded in the real world, but it displays women's role in marital relationships as patiently obedient to their husbands, thereby conveying culturally-constructed moral values regarding the ceremony and ritual of marriage, taken as a lifelong commitment in which women are subordinate to men. In other words, by the early modern period Griselda had become the archetype of the patient, obedient and meek-that is to say ideal-wife, and her story a myth aimed at maintaining social order and gender hierarchy.

Consequently, at the turn of the sixteenth to seventeenth century, in an age in which the Reformation and the Counter-Reformation still debated the social and religious status of marriage, it seems only natural that Thomas Dekker, Henry Chettle and William Haughton in England and Félix Lope de Vega Carpio in Spain should have turned to the Patient Griselda myth to theatrically engage with the socio-political issue of the marital union.

Given that French versions in particular influenced some of the English and Spanish rewritings and translations, it is difficult to find a precise source or the specific textual realisation(s) of the myth on which the English and Spanish writers based the early modern plays I wish to analyse: Dekker, Chettle and Haughton's The Pleasant Comedy of Patient Grissel composed towards the end of 1599 and printed in 1603; and Lope de Vega's El ejemplo de casadas o prueba de la paciencia written between 1599 and 1603 and printed in 1615 in Madrid and in 1616 in Barcelona. ${ }^{11}$

\footnotetext{
9 For a survey of all the adaptations of the story in Europe and beyond from the fourteenth until the twentieth century, see Raffaele Morabito, "La diffusione della storia di Griselda dal XIV al XX secolo," Studi sul Boccaccio 17 (1988), pp. 237-285.

10 To mention but a few examples of the appearance of Griselda's name in early modern literature: William Forrest in 1558 wrote a hagiographical poem on the life of Catherine of Aragon renaming her "Grisild" (The History of Grisild the Second); in Shakespeare's The Taming of the Shrew, Petruccio claims that Catherine "[f]or patience [...] will prove a second Grissel” (William Shakespeare, The Taming of the Shrew [1623]: Texts and Contexts, ed. Frances Elizabeth Dolan [Boston, MA/New York, NY: Bedford Books of St. Martin's Press, 1996], 2.1.288).

11 Regarding the date of the play, see Marie-Françoise Déodat-Kessedjian and Emmanuelle Garnier, "Prólogo," in: Félix Lope de Vega Carpio, Comedias de Lope de Vega: Parte V [1615], ed. Marie-Françoise Déodat-Kessedjian and Emmanuelle Garnier (Lleida: Milenio, 2004), pp. 35-48, pp. $35 \mathrm{f}$.
} 
However, these plays still attest to a cultural transfer from Boccaccio's Italian text into Spanish and English cultures. While the story had achieved cultural relevance all across Europe by the end of the sixteenth century, it still bore many features of its Boccaccian realisation, especially in terms of the Aristotelian mythos or plot that I have summarised above: the storyline and its various narremes ${ }^{12}$ of a wife of poor origins whose obedience and patience are tested by the taking away of her children, repudiation and active participation in the preparation of her husband's second wedding are clearly identifiable in both plays. At the same time, the novella underwent processes of acculturation or nationalisation, that is to say, both plays display English and Spanish traits, respectively.

In the English comedy the plot is all the more recognisable since not only the Italian setting in the town of Saluzzo and the surrounding area, but also the only three names Boccaccio gave to characters in the novella are preserved, though in English form. Following a tradition starting with Chaucer's retelling of the story in the Clerk's Tale, which turned Griselda's name first into Grisilde and, from the 1560s, into Grissil or Grissel, Dekker, Chettle and Haughton's Griselda is called Grissil. The same tradition has Gualtieri, the marquis, become alternatively Walter, Gautier or Gualter; the latter is the name retained by the playwrights. Griselda's father, Giannucole, in English rewritings becomes Janicola or Janicle; the former is the name used by Dekker, Chettle and Haughton.

The playwrights open their plays with a hunting scene in which the marquis's courtiers, Mario, Lepido and his brother, the marquis of Pavia, complain that Gualter promised to get married on this day but does not seem to be willing to keep his promise. The marquis actually leads them to Grissil's home. She is not a shepherdess but the daughter of a basket-maker and she has a servant, Babulo, the play's fool, and a brother, Laureo. Gualter asks both Janicola's and Laureo's consent to marry Grissil. When all agree to the match-Grissil includedthe marquis not only brings his bride to his palace in Saluzzo but also invites the entire family to come and reside with them. As Grissil is about to give birth to twins, Gualter starts testing her. He first pretends to be angry at her by claiming that his subjects despise her for being low-born, and treats her worse than his own servants. Then, he banishes her family from court. When Grissil gives birth to her daughter and son, he continues his testing: he repudiates her and sends his wife and children back to the countryside. Shortly afterwards, Gualter orders Furio, his faithful servant, to go and take the babies from Grissil and to

12 I use narreme as the smallest unit of narration of prose narratives (e.g. Boccaccio's novelle), as well as of plays, following Helmut Bonheim's application of the term to drama in order to identify common narrative patterns from one play to another (see Helmut Bonheim, "Shakespeare's Narremes," Shakespeare Survey 53 [2000], pp. 1-11). 
pretend to kill them while actually bringing them to Pavia to have them raised by his brother. Finally, he asks Grissil and her family to come back to Saluzzo to prepare his second wedding, which never takes place since the bride and her brother are Grissil's children. The marquis reveals who they are and celebrates Grissil's patience and restores her father's, brother's and servant's place at court. In addition Dekker, Chettle and Haughton devised two contrasting subplots with completely new material not present in any previous versions of the myth. The first one presents a Welsh lady, Gwenthyan, a widow and a shrew, once married to the marquis's late cousin, who marries a Welsh knight, Sir Owen ap Meredith. Their married life offers a parody and comic counterpart to Grissil's trials. In the second subplot, Julia, the marquis's sister, is courted by several suitors but prefers to remain a virgin and all the more so as she witnesses the married lives of the Welsh couple and that of her brother and Grissil.

Thus, while Dekker, Chettle and Haughton acknowledge and keep the Italian setting of the myth and create new characters to whom they give Italian names (Mario, Lepido, Babulo Furio, etc.), the English writers stick to the anglicised spellings derived from the reception of the story in England for the characters of Griselda, her father and the marquis. Moreover, the dramatists accentuate the British coloration of the myth by introducing the Welsh figures of Sir Owen ap Meredith and Lady Gwenthyan, as counterparts for Gualter and Grissil. Welsh characters were common on the early modern English stage, especially for comic purposes as is the case here. The unlikely presence of the Welsh couple in Saluzzo and the name changes into Grissil, Gualter and Janicola suggest that the Griselda myth had by then become part of English literary tradition and had acquired English traits.

Lope de Vega, while clearly using the myth as his basic plot structure, went further than the English playwrights in the process of acculturation: unlike any previous Spanish versions of the myth, he situated the comedia's action on the Iberian Peninsula, in Catalonia, and gave Spanish names to all the characters: Griselda becomes Laurencia; Gualtieri, the marquis, becomes the Conde "Enrico de Moncada;"13 and Griselda's father Giannucole is now Lauro. ${ }^{14}$

13 All references to the play come from Lope de Vega, El ejemplo de casadas y prueba de la paciencia, in: Comedias de Lope de Vega: Parte V, pp. 51-133, and will be cited parenthetically by verse number in the text; here v. 29. All the translations are mine.

14 For more on the myth's realisations in Spain, see Caroline Brown Bourland, "Boccaccio and the Decameron in Castilian and Catalan Literature,” Revue Hispanique 12 (1905), pp. 163189, 211-214; Isidoro Pisonero del Amo, "Un motivo boccacciano: 'La paciente Griselda' en la literatura española,” in: Pedro Peira, ed., Homenaje a Alonso Zamora Vicente, 5 vols. (Madrid: Castalia, 1992), vol. 3, pt. 2, pp. 221-241; Juan Carlos Conde, "Un aspecto de la recepción del 
The comedia begins with Enrico's courtiers entreating him to get married. Although he promises he will do so, he delays the moment of choosing a wife by going hunting and by giving audience to prisoners hoping to obtain his grace. The latter activity has no precedent in other Spanish versions of the tale and expands the myth's engagement with social issues, since the cases presented to the Conde all concern marriage. After pardoning all the prisoners, Enrico goes hunting again and then meets Laurencia. He immediately determines to marry her, which he does after obtaining both her and her father's consent. After Laurencia gives birth to a daughter and sometime later to a son, Enrico starts testing her by asking his servant Tibaldo to take away her daughter in order to have the child killed. The Conde then asks Laurencia for his son and pretends to have him too killed. Shortly afterwards, Enrico repudiates her and sends her back to her father. After spending several years in the countryside with her father, an additional character absent from previous rewritings, the widowed prince of Bearn, having heard of Laurencia's virtues, sends her a messenger to ask for her hand. At the same time another messenger arrives from Enrico's court to bid her to come back to the Conde's castle and prepare his second wedding. Laurencia rejects the prince of Bearn's offer on the grounds that she is still Enrico's wife and leaves to take care of the marriage celebration. Enrico's second nuptials never take place since he reveals that his supposed bride and her brother are Laurencia's children. The family is reunited and Laurencia's patience greatly praised.

By moving the myth's setting from Italy to Spain and giving his characters new Spanish names and titles, Lope turns Griselda and the marquis into Spanish figures. He even makes them appear to belong to Iberian history by setting the play during the time of the Third Crusade (1189-1192), in which Enrico is said to take part with the real historical figures of the English king Richard the Lionheart and the Spanish king Alfonso VIII. Though the latter did not actually take part in the Crusades, he was famous for his successful battle of the Navas de Tolosa against the Moors in 1212 during the Reconquista and, thus, helps to endow the play with an aura of national chronicle and legend. Consequently, through this process of nationalisation, Lope turns the Italian story into a Spanish legend.

The theoretical framework elaborated by the DramaNet research group, which considers culture as a net, helps us to consider the source problem from a new perspective and provides a metaphoric explanation of how Lope and Dekker, Chettle and Haughton, though separated in spatial terms, worked on plays presenting the same story. Culture, understood as "conscious concepts" and their

Decameron en la Península Ibérica, a la sombra de Petrarca. La historia de Griselda," Cuadernos de Filología Italiana Special Issue (2001), pp. 351-371. 
"material forms," 15 when envisaged through the metaphor of a net, in which these concepts and their material forms float without a necessarily clear starting point and circulate beyond national borders or within countries, allows for a better understanding of how the Griselda myth could be used in England and Spain at the same time. This story was readily available as a concept, plot or set of narremes and in material forms (books, manuscripts, paintings) not only within the respective English and Spanish cultural nets but also within the European cultural net. Therefore, Lope de Vega, Dekker, Chettle and Haughton could easily have come across the story in one of its oral, written or pictorial realisations and chose to shape it into a comedia and an Elizabethan play, respectively. In addition, this shaping process produced similarities, which the cultural net can also account for, despite inherent generic differences between early modern Spanish theatre and English drama.

By comparing these two plays I wish to demonstrate that, firstly, it is significant that they both freely elaborate the myth's treatment of marriage more than any previous version; and, secondly, that they used similar techniques, which belonged to English and Spanish literary traditions or cultural nets, to address social anxieties about the life-changing nature of marital commitment. My analysis, therefore, focuses on some of the additional material rather than on the main story of the myth.

Both Lope's and Dekker, Chettle and Haughton's works introduced new characters. These are mainly stock figures extremely common in early modern English and Spanish drama, which they could have picked up either by simply attending or reading plays by other contemporary dramatists or from their knowledge of classical Latin drama. ${ }^{16}$ The English playwrights and Lope also enlarge the Griselda myth with new episodes or subplots. While this additional dramatic material can in both cases be related in terms of narremes to other contemporary plays, indicating their thematic affiliation with English and Spanish literary traditions or cultural nets respectively, in the English play the affiliation is also

15 See Joachim Küpper's article in this volume.

16 Although little is known about Haughton's or Chettle's education, Dekker most likely attended grammar school, where he could have become familiar with Latin authors. At any rate Dekker's mastery of Latin is attested by his English translation of the Latin poem Grobianus by Friedrich Dedekind (see John Twyning, “Dekker, Thomas [c. 1572-1632]," in: Henry Colin Grey Matthew and Brian Harrison, edd., Oxford Dictionary of National Biography [Oxford: Oxford University Press, 2004], online ed., ed. Lawrence Goldman, 2008, http://www.oxforddnb.com/ view/article/7428 [retrieved: 14 June 2012]). Lope's proficiency in Latin and thorough knowledge of classical literature is well attested by his Jesuit education and numerous references to Latin and Greek authors throughout his work. 
formal, given that, like Elizabethan drama in most of its instances, it presents a complex dramatic structure with a main plot and two subplots. Finally, in terms of literary language, both in Patient Grissil and El ejemplo de casadas, a rhetoric of the monstrous or grotesque is used in order to exorcise through laughter anxieties about getting married. Monstrosity and the grotesque were commonly employed in early modern Spanish and English literatures, especially in satirical writings, such as those of Quevedo or Gracián in Spain, ${ }^{17}$ whose works Lope could have read; and Dekker was himself a satirist who made use of such metaphorical language, especially of the grotesque, in his pamphlets, following an early modern English tradition of pamphleteers who used these rhetorical techniques as means of denouncing contemporary vices by enhancing their repulsive features and/or making them appear comic. ${ }^{18}$

The topic of marriage, in the early modern period, is at the centre of many writings of various natures-literary and non-literary: sermons, ballads, conduct books, laws, plays etc. As a rite of passage and a central device that structures society, marriage has attracted much attention over the centuries, all the more so during certain transitional periods such as the sixteenth and seventeenth centuries, when the Reformation brought radical changes to religious rituals and doctrine.

On the one hand, following Lutheran and Calvinist arguments that virginity is not holier than marriage and that marriage was ordained by God for all men and women without exception, ${ }^{19}$ Protestant England started allowing priests to marry during Edward VI's reign, but prohibited it again during Mary I's Catholic rule and made it lastingly lawful under Elizabeth as part of the Thirty-Nine Articles of Religion (1563), ${ }^{20}$ which also denied marriage's sacramental status and redefined it as a civil contract. ${ }^{21}$ On the other hand, Catholic Europe, to which Spain belonged, convened at the Council of Trent (1545-1563) to condemn Protestant-

17 For the specific use of the monstrous as a satirical device in Gracián and Quevedo, see Jorge Checa, "Figuraciones de lo monstruoso: Quevedo y Gracián," La Perinola: Revista de investigación quevediana 2 (1998), pp. 195-211.

18 For the use of the grotesque in early modern English literature, see Neil Rhodes, Elizabethan Grotesque (London: Routledge, 1980); and Kathryn Michelle Brammall, "Monstrous Metamorphosis: Nature, Morality, and the Rhetoric of Monstrosity in Tudor England," The Sixteenth Century Journal 27.1 (1996), pp. 3-21.

19 See Theodora Ann Jankowski, Pure Resistance: Queer Virginity in Early Modern English Drama (Philadelphia, PA: University of Pennsylvania Press, 2000), p. 11.

20 Gwendolyn Bridges Needham, "New Light on Maids 'Leading Apes in Hell', 'The Journal of American Folklore 75. 296 (1962), pp. 106-119, p. 107.

21 Christine Peters, "Gender, Sacrament and Ritual: The Making and Meaning of Marriage in Late Medieval and Early Modern England,” Past and Present 169. 1 (2000), pp. 63-96, pp. 77-78. 
ism as a heresy, to reaffirm Catholic doctrine and to redefine some of its aspects, including marriage. While the decrees of the Council restated the more elevated status of virginity and chastity, the necessity of celibacy for priests, the sacramental nature of matrimony and its indissolubility even in the case of adultery, they also revised marriage doctrine to solve the problem of clandestine unions. The Council took a series of measures to achieve greater control over marriage and its lawfulness: it rendered obligatory the publication of bans and the public enactment of betrothal sanctified by a priest at the church doors and removed the obligation of parental consent to produce a valid union, thereby endowing both men and women with complete freedom of choice of partner-a necessary freedom, given that any sacrament has to be willingly accepted and performed, if the person is an adult, in order to be valid..$^{22}$ For Protestants, on the contrary, parents' approval was indispensable.

However, many European Catholic countries had civil laws countering the Tridentine decree and requiring parental consent for marriages. The application of the Council of Trent's decisions was far from smooth and led to legal conflicts within some families whose elders tried to impose marital unions on unwilling children. ${ }^{23}$ In Protestant England similar familial tension could arise when children married "clandestinely" through spousals only, that is to say, by exchange of vows per verba de praesenti in front of a witness: while spousals even without parents' approval were enough to make a marriage legal, according to civil law, as Barnett and Mary Sokol explain, marriage by spousals only was "viewed as an offence by both society and Church law. [...] especially families [...] deplored the excessive freedom [...] allowed a bride and groom.”24

Regarding marriage's indissolubility, most Protestants thinkers were more flexible than Catholics, usually considering adultery a ground for divorce, and allowing spouses to separate-that is to say, to live under different roofs, yet not remarry-on various grounds such as impotence or insanity, among others. ${ }^{25}$ In practice, however, as Barnett Jerome and Mary Sokol explain:

22 Gabriela Carrión, Staging Marriage in Early Modern Spain: Conjugal Doctrine in Lope, Cervantes, and Calderón (Lewisburg, PA: Bucknell University Press, 2011), p. xiii.

23 See Ignacio Arellano and Jesús María Usunáriz, edd., El matrimonio en Europa y el mundo hispánico: Siglos XVI y XVII (Madrid: Visor Libros, 2005); Jesús María Usunáriz and Rocío García Bourrellier, edd., Padres e hijos en España y el mundo hispánico: Siglos XVI y XVIII (Madrid: Visor Libros, 2008).

24 Barnett Jerome Sokol and Mary Sokol, Shakespeare, Law, and Marriage (Cambridge: Cambridge University Press, 2003), pp. $14 \mathrm{f}$.

25 David L. Smith, "Divorce and Remarriage From the Early Church to John Wesley," Trinity Journal 11. 2 (1990), pp. 131-142, pp. 138-140; Sokol et al., Shakespeare, Law, and Marriage, pp. 140-142. 


\begin{abstract}
In early modern England once a man and woman were validly married they remained bound to each other for as long as they lived, for better or worse, because divorce in its modern sense was not available. If a marriage failed the church courts were sometimes able to grant an order for one of two kinds of divorce, but neither corresponds to the modern law of divorce. Firstly, the church courts could grant a divorce a vinculo matrimoni. Here a marriage was annulled if the courts found a "dirimentary impediment" making the marriage void ab initio-it had never existed. The parties could then be free to marry again. Secondly, the church courts could make an order for a divorce a mensa et thoro. Here husband and wife were freed from their legal duty to cohabit, but they were not free to remarry. This kind of divorce more nearly corresponds to modern judicial separation. ${ }^{26}$
\end{abstract}

In addition, it was extremely rare that someone actually separated or obtained a marriage annulment, mainly because financially these were expensive to obtain, and socially marriage breakdown brought dishonour and shame, as Elizabeth Foyster has demonstrated. ${ }^{27}$

As far as ritualistic practices were concerned, not only was there no fixed rule and a lot of diversity in practices, but as Christine Peters demonstrates, the liturgical changes regarding marriage initiated by the Reformation in England were either not very specifically Protestant or had little impact on the laity's representation of marriage: for example, English Protestants' transfer of the ceremony inside the church building was a phenomenon that could also be observed in Catholic France. ${ }^{28}$

As regards Catholic and Protestant advice literature, Peters also remarks that the constitution of marriage as a civil contract was accompanied by much insistence on its holiness and blessedness, and the fact that spouses had to "live well" in order to achieve salvation, if, and only if, one was touched by God's grace. Such were conceptions that were similar to Catholic admonitions to spouses to behave properly. ${ }^{29}$ As Kathleen Davies argues, the English Protestant and European Catholic treatises on marriage, which aimed to educate the laity on the purposes and lawfulness of marriage, how to choose a wife, how to be a good wife or husband and how marriage was to be hierarchised-the husband being head of the family and the wife his subordinate-did not significantly differ, except for some rare Protestant invectives against virginity. ${ }^{30}$

26 P. 139.

27 Elizabeth Ann Foyster, Manhood in Early Modern England: Honour, Sex and Marriage (London/New York, NY: Longman, 1999), esp. pp. 10-13.

28 Peters, “Gender, Sacrament and Ritual," pp. 77-80.

29 P. 77.

30 Kathleen M. Davies, "Continuity and Change in Literary Advice on Marriage," in: Richard Brian Outhwaite, ed., Marriage and Society: Studies in the Social History of Marriage (London: Europa Publications Limited, 1981), pp. 58-80. 
This suggests that early modern Catholics and Protestants had converging views on various theoretical aspects of marriage: providing more children, i.e. Christians for God's service; a means to avoid lechery; and the perpetuation of the divine order of things, in which the wife is subjected to her husband's will. Additionally, in practice, similar conflicts about the choice of spouses could arise as much in Spain as in England; and while divorce was prohibited in Catholic countries, reformed England did not socially favour it, despite the existence of legal means of separation.

As a consequence, similar anxieties regarding marriage could arise in both Spain and England. Thus the Patient Griselda myth, with its long recognised didactic potential to teach women how to be meek, obedient and most of all patient wives, as well as its initial attention to a ruler's reluctance to get married, could serve similar purposes regarding marriage on both the Protestant English and Catholic Spanish stages.

The Comedy of Patient Grissil and the Ejemplo de Casadas freely enlarge the tale in order to address the question of embracing marital status, and the implications of marriage for an individual and for her or his family or the larger community. This issue raises anxiety in more than one character in these plays in so far as, according to the Freudian definition, it generates "a particular state of expecting the danger or preparing for it, even though it may be an unknown one."31

Marriage, as anthropologists from Van Gennep onwards have commented, is a social enterprise and not an individual's freely made choice: it is influenced by one's family and/or community and has repercussions on one's life and on one's community. ${ }^{32}$ Contemplating the consequences of marriage on one's life or social group can generate anxieties in the individual entering matrimony as much as in members of her or his circle of close relations.

Among the possible anxieties this could produce, I will first consider the fear experienced by subjects whose ruler refuses to marry, an anxiety the early modern Spanish and English audiences may have shared.

Lope de Vega opens his play with his Conde acknowledging the validity of his subjects' marriage petition in terms of succession: he says, "Vasallos, yo os agradezco / vuestra justa pretensión; / deseo la subcesión” (vv. 1-3) [Vassals, I thank you / for your request; / I want succession]. Similarly, Dekker, Chettle and

31 Sigmund Freud, Beyond the Pleasure Principle [Jenseits des Lustprinzips, 1920], in: The Standard Edition of the Complete Psychological Works of Sigmund Freud, edd. and trans. James Strachey, Anna Freud, Alix Strachey and Alan Tyson, 24 vols. (London: The Hogarth Press, 1955), vol. 18, p. 12.

32 See Arnold Van Gennep, Les rites de passage (Paris: Libraire Critique Emile Nourry, 1909), esp. chap. 7, pp. 165-207. 
Haughton's first scene presents the marquis's brother and courtiers complaining that their lord is carelessly hunting instead of answering the various neighbouring rulers' offers of their daughters or other female relatives in marriage: "This day you vowed to wed: but now I see, / Your promises turne all to mockerie," 33 reproaches the marquis of Pavia, Gualter's brother; Lepido, his courtier, continues, “This day your self appointed to giue answere / To all those neighbour-Princes, who in loue / Offer their Daughters, Sisters and Allies, / In marriage to your hand." (1.1.22-25).

These two opening scenes reveal that, as a ruler, the marquis or Conde cannot choose not to marry without provoking discontent. Moreover, as the English playwrights only imply and Lope explicitly states, what is at stake in a ruler's marriage is his succession. If a king died without an heir, his realm would face wars, which would destroy and divide the country until one among various, more or less legitimate pretenders to the throne emerged victorious. Yet, in both plays, the subjects' fear is ungrounded because Gualter and Enrico are young and still have time to find a wife and have legitimate children to succeed them after their death.

Although Spanish successions had occurred quite smoothly for more than a century when Lope's play was composed (c. 1599-1603), the fact that Philip II died in 1598 may have awakened anxieties, even though he was succeeded by his 22-year-old son, Philip III: the new king was not married when he inherited the throne; and it had taken his father more than fifty years and four marriages to have a son who would survive him.

The opening scene of the Ejemplo de casadas stresses the importance that a ruler provide an heir, as we have seen, which is echoed twice in the third act, in two passages not present in previous versions of the myth. First, after Laurencia is sent back to her father, Enrico wishes to embark on a crusade. His courtiers, Floriano and Celio, try to persuade him to stay and ask for a papal dispensation in order to remarry: "FloRIANO: Sin sucesión nos dejas" [FLo.: You leave us without succession]; “CELIo: [...] Mira, señor, en qué aflicción nos dejas” [CEL.: [...] Look, my lord, in what affliction you leave us]; "Flo.: [...] escribe al Santo Padre que disponga / por causa tan ligítima” [FLo.: (...) write to the Holy Father to have him decide on this legitimate case] (vv. 2200, 2203, 2213 f.). Secondly, when the prince of Bearn appears, he explains that his wife is dead and that he has no heir, but twice promises his courtiers, Rosardo and Anselmo, that he will remarry to provide them with a rightful heir: "casarme y daros prometo / ligítima sucesión"

33 All references to the play come from, Thomas Dekker, Henry Chettle, William Haughton, Patient Grissil [1603], in: The Dramatic Works of Thomas Dekker [c.1590-1629], ed. Fredson Bower, 4 vols. (Cambridge: Cambridge University Press, 1953), vol. 1, pp. 207-298, and will subsequently be given in parenthesis in the main body of the text; here 1.1.20 $\mathrm{f}$. 
[I promise to get married and give a legitimate succession], he affirms and reiterates, a few lines later, "y os daré a todos contento, / y sucesión a mi estado" [and I will give you all satisfaction, / and succession for my estate] (vv. 2267-68, 227576). Lope may have, thereby, been trying to encourage his new king to marry and quickly have children.

On the other hand, England was facing a much more problematic situation: in 1599, when Dekker, Chettle and Haughton wrote their comedy, the Queen, Elizabeth I, was already 66 years old, unmarried, refusing to get married and undoubtedly a post-menopausal woman. She additionally did not want to name a successor, and continued to refuse to do so until she was on her deathbed. To write or speak about the succession was punishable by a year's imprisonment; and anyone daring to question her political abilities was equally in danger of prison. ${ }^{34}$ Therefore, playwrights had to be careful if they wished to address this delicate issue. This may explain why Gualter is never really unwilling, reticent or afraid of getting married, unlike Lope's Conde Enrico. The marquis's initial carelessness about marriage is a mere joke he plays upon his courtiers. Although he briefly protests that his brother and his courtiers wish to force his "free thoughts into the yoake of loue, / To grone vnder the loade of marriage," which he calls a "burthen" (1.1.61 f., 63), he has actually already made up his mind to marry Grissil: he had seen her before and courted her for a while (as we learn in Act 1 scene 2).

However, Dekker, Chettle and Haughton still seem to address the controversial issue of Elizabeth's lack of an heir, not to convince the queen to have children, since this was beyond hope, but to ridicule her egoistic cult of virginity and suggest she should have been more far-sighted and married to secure her succession with legitimate offspring. Therefore, they employ a group of stock characters who could easily be grafted onto Griselda's story in a typically Elizabethan subplot: Julia, the marquis's sister, a virgin unwilling to get married, and her suitors, Farneze, Onophrio and Urcenze. From her very first appearance in Act 2 scene 1, she rejects wedlock on the grounds that she deems it "a kinde of hell" (1. 259) and compares it to war: "You may well call that a combat, for indeede marriage is / nothing else, but a battaile of loue, a friendly fighting, a kinde of / fauourable terrible warre" (2.1.273-75). Julia also claims, "I deale by marriage as some Indians doe the Sunne, adore it, / and reuerence it, but dare not stare on it, for feare I be starke / blinde" (2.1.276-78; my italics, except for "Indians"). These metaphors underline her anxiety, yet she has so far no reason

34 See Cyndia Susan Clegg, Press Censorship in Elizabethan England (Cambridge: Cambridge University Press, 1997), p. 32. 
to fear: Julia has never entered wedlock, and she has not witnessed yet what married life is for the other couples of the play, Gualter and Grissil, and Sir Owen and Lady Gwenthyan. Julia prefers to remain unmarried because, apparently following Catholic doctrine, she values virginity over marriage: "sweet virginitie is that inuisible God-head that turns vs / into Angells, that makes vs saints on earth and starres in heauen: / heere Virgins seeme goodly, but there glorious." (2.1.263-65)

Julia is an Italian lady, sister to the marquis and not an English queen, in other words, removed from Elizabeth by her nationality and political position, but of equal rank and gender. Moreover, her Catholic arguments, placing virginity above the married status, can be read as a rhetorical gesture comparable to Elizabeth's self-fashioning as a Virgin Queen. Elizabeth I used the cult of the Virgin Mary, appropriating Marian poetics and pictorial representations, and combining these with her symbolic marriage to her nation as a device that allowed her to "receive the adulation of her subjects as the universal object of a Petrarchan religion of love, one that pervaded ballads, pageants, and dramatic entertainments" (as John King nicely summarises). ${ }^{35}$ Similarly, Julia employs her plea for virginity as a means to disdain her suitors, while encouraging them to follow her "religion of love": "In heauen is no / wooing yet all there are louely: in heauen are no weddings yet al /there are louers" (2.1.265-67). The marquis's sister enjoys the power she has over her suitors and treats them like pets: "oh for a Drum to summon all my louers, my / suiters, my seruants together" (ll. $177 \mathrm{f}$.), she wishes in Act 4 scene 3, to which they answer in echoing terms: "FARNEzE: I appeare sweet mistresse without summons. / ONOPHRIO: So does Onophrio. / URCENZE: So does Vrcenze." (1l. 179-181)

Julia is no queen; but her ridiculous power over no less ridiculous followers clearly parodies Elizabeth I and her handling of her court and worshippers.

In addition, the virginity of the marquis's sister is presented as anomalous and monstrous. In Act 2 scene 1, trying to make sense of Julia's rejection of lovers and marriage, Farneze says: "Then I perceiue you meane to leade apes in hell" (1. 257). As Gwendolyn Needham comments, this English expression most likely "originated in Protestant feeling against celibacy" and "[b]y its prediction of punishment in hell, the proverb expresses not mere derogation, but condemnation of celibacy as a positive evil." 36 "In proclaiming the doom of the unmarried," Needham further contends, in its secular meaning "the proverb implicitly argues

35 John N. King, "Queen Elizabeth I: Representations of the Virgin Queen,” Renaissance Quarterly 43.1 (1990), pp. 30-74, p. 30.

36 Needham, "New Light on Maids," pp. $106 \mathrm{f}$. 
for the perpetuation of the race, recognizes the social and economic necessity of woman's prompt marriage, and criticizes wayward female nature." ${ }^{37}$ The proverb casts Julia either as a barren woman followed by apes that stand as substitute children, or as a monstrous mother who gave birth to apes in hell. As Needham reminds:

As subman, the ape was believed capable of intercourse with woman and ever ready to ravish her. A symbol of sin and sexuality, the ape was often placed in contrast with the unicorn, the symbol of chastity and of Christ. As a fool, the ape's imitative nature permitted his representing all kinds of follies as well as vices-a valuable instrument for humor and satire. ${ }^{38}$

Furthermore, Julia's suitors can also be likened to apes, for they can barely be differentiated from one another and some of their cues (such as those previously cited) echo or mimic each other. Thus, they might become the apes Julia will lead in hell.

Association of celibacy with monstrosity was not uncommon in the early modern period. If not monstrous, virginity was at least considered unnatural or anomalous by Protestant thinkers. Luther, in his "Sermon at Merseberg" (1545), states: "Who commanded you to vow and swear something which is contrary to God and his ordinance, namely, to swear that you are neither a man or a woman, when it is certain that you are either a man or a woman, created by God." ${ }^{39}$ Thomas Becon, in his preface to the 1541 edition of the English translation of Heinrich Bullinger's Der christliche Ehestand, writes: "Lette other prayse suche [i.e. those who vow to remain virgins] as maye iustly seme to be monstures of nature for theyr sterrilite and barrennes." ${ }^{\text {"0 }}$ Moreover, as Theodora Jankowski argues, Elizabeth I was indeed an "anomalous" figure, as a "Virgin Queen and eternally desired love object"41-a definition which perfectly suits Julia (except for the royal title).

37 P. 110.

38 P. 112.

39 Martin Luther, “Sermon at Merseburg [1545]," in: Luther’s Works, edd., Helmut T. Lehmann and Jaroslav Pelikan, 55 vols. (St. Louis, MO: Concordia Publishing; Philadelphia, PA: Fortress Press, 1958), vol. 51: Sermons I, ed. and trans. John W. Doberstein, p. 362, quoted in Jankowski, Queer Virginity, p. 11.

40 Heinrich Bullinger, The golde[n] boke of christen matrimonye (London: Joh[a]n Mayler, 1542), sig. A3r. This book went into nine editions until 1575 (see Needham, "New Light on Maids," p. 109). For an extended analysis of this passage see Eric Joseph Carlson, "Clerical Marriage and the English Reformation,” Journal of British Studies 31.1 (1992), pp. 1-31, p. 9.

41 Jankowsky, Pure Resistance, p. 13. 
Consequently, Dekker, Chettle and Haughton seem to have employed the marquis's sister, on the one hand, to parody Elizabeth's cult of virginity and thereby exorcise social anxiety concerning her succession by turning this fear into laughter over the cause of the situation-the Queen's refusal to marry and have children-and, on the other hand, more generally, to ridicule those who shun love and are afraid of marriage.

However, as the play unfolds, yet another interpretation emerges: Julia's fears gradually appear more grounded and comprehensible, so she becomes the voice of men and women oppressed by marital life. Julia, throughout the play, occupies the position of witness and judge, contemplating and drawing moral conclusions about the marquis's cruel testing of Grissil and about Gwenthyan and Sir Owen's comical fight over the right to rule over their marriage. Gwenthyan being a shrew and Sir Owen a braggart knight, the display of their married life gives way to much humorously staged tension. Julia's particular position, aside from the action, transforms her into an audience member within the play, a function she shares with her suitors. Julia and her followers even acknowledge their status as spectators: Urcenze predicts that the union between Gwenthyan and Sir Owen will be a conflict, calling it a "welch tragedie" (2.1.230); and Julia refers to the "enterlude" (4.3.173) when speaking of the episode in which Gwenthyan dresses in rags and serves some beggars the banquet prepared for the marquis and his court. The audience is, thereby, invited to identify with Julia; and some members of the audience may have shared her fear and rejection of marriage, a fear reinforced by her witnessing the other characters' marital behaviour throughout the play.

Moreover, Julia's status as spectator-within-the-play makes her a suitable character to begin the comedy's tripartite epilogue. Interrupting her brother and preventing him from reciting the conclusion of the play and celebrating Grissil's patience, she says:

\footnotetext{
Nay brother your pardon awhile: besides our selues there are a number heere, that haue beheld Grissils patience, your owne tryals, and Sir Owens sufferance, Gwenthians frowardnes, these Gentlemen louertine, and my selfe a hater of loue: amongst this company I trust there are some mayden batchelers, and virgin maydens, those that liue in that freedome and loue it, those that know the war of mariage and hate it, set their hands to my bill, which is rather to dye a mayde and leade Apes in hell, then to liue a wife and be continually in hell. (5.2.275-283)
}

Here Julia tries to use the proverb "to lead apes in hell” to serve her own interest, like Beatrice in Shakespeare's Much Ado About Nothing. As Needham remarks: "[Beatrice] declares that the predicted punishment applies no more to lively 
maids than to gay bachelors. Delivering her apes to the devil at the gate, she will 'away to St. Peter for the heavens: he shows me where the bachelors sit, and there live we as merry as the day is long' [...]." 42

Julia gestures towards a similar attitude and employs the proverb as a self-asserting means to express her determination to remain a virgin and oppose those who favour marriage: she prefers "to dye a mayde and leade Apes in hell, then to liue a wife and be continually in hell.” The phrase helps Julia in stressing through an epistrophe ("in hell”) that, in her opinion, marriage is for women an extremely painful and inescapable experience. "Society tolerated a high level of violence against wives as a normal feature of domestic relations," as Sara Mendelson and Patricia Crawford explain. ${ }^{43}$ Moreover, a wife's belongings-financial and material-were her husband's. So it was harder for women not only to find the means to start legal action against their husbands, but also to obtain a separation a mensa et thoro. Even if neither the shrewish Gwenthyan nor the cruelly mistreated Grissil wish to be separated from their spouse, Julia expresses her impression that, regardless, there is no way out of marriage, and that wedlock is, thus, a hellish torment on earth.

However, the proverb also punishes Julia with everlasting life in hell. While she acts as the voice of men and women oppressed by marriage, and of wives in particular, the dramatists undermine her plea for freedom, probably to avoid an accusation of sedition or of being Papists. ${ }^{44}$ Such a plea was contrary to Protestantism, which condemned all forms of celibacy. Therefore, Julia does not speak the last words: Gwenthyan silences her and accuses her of "abus[ing] yong mens and damsels" and scaring them away from "good sportes and honorables states" $(5.2 .285,286)$. And the conclusion of the play falls to Sir Owen, who gets tangled up in his plea for patience in marriage:

\section{[...] if sir Owen was \\ not patient, her Latie had not beene pridled, if Grissill had not \\ beene patient her cozen Marquesse had not been pridled: well now \\ if you loue sir Owens Latie, I hobe you loue Sir Owen too, or is grow \\ mighty angry, Sir Owen loue you as God vdge mee out a cry, a \\ terrible teale, doe you heare now, they pray awl that haue crabbed}

\footnotetext{
42 Needham, "New Light on Maids", p. 112 (the quote from Shakespeare comes from: William Shakespeare, Much Ado About Nothing [1600], ed. Claire McEachern, The Arden Shakespeare, 3rd Series [London: Thomson Learning, 2006], 2.1.41-44).

43 Sara Heller Mendelson and Patricia Crawford, Women in Early Modern England: 1550-1720 (Oxford: Oxford University Press, 1998), p. 140.

44 For more on Elizabethan censorship of Catholic and "papistical books" see Clegg, Press Censorship, chap. 4, pp. 79-102.
} 


\begin{abstract}
husbands and cannot mend them, as Grissils had, and awl that haue fixen wiues, and yet is tame her well enough as sir Owen does, and awl that haue scoldes as sir Owen does, and awl that loue fair Laties as sir Owen does, to sed her two hands to his pill, and by God shall haue sir Owens heard and soule in his pellie: and so God saue you all. Man gras wortha whee, Man gras wortha wee. [i.e. My grace is to you] God night Cozens awl. (5.2.301-313)
\end{abstract}

Sir Owen's comic confusion can be interpreted as an attempt to remind the audience that marital problems should be laughed at, and should not generate anxieties. Yet, Julia's voice may have resonated past Sir Owen's last words and made a favourable impression on the audience, among those spectators who may have preferred to remain bachelors and virgins, either because they were Catholic or as a life choice without any religious motivation, simply because they wished to be freed from the social obligation to get married and its consequences. ${ }^{45}$ Given that no man-not even her brother the Marquis-forces Julia to enter wedlock or condemns her speeches, she embodies a greater threat to patriarchal values and to social order than the play's shrew, who wants to rule over her husband. So Gualter's sister had to be silenced (yet by a woman, Gwenthyan) and sentenced to hell (yet by herself) in order for the playwrights and the Admiral's Men to safely stage and, later, have the play printed.

Whereas Dekker, Chettle and Haughton present Julia and her fear of marriage from a ridiculous perspective at the beginning of the play, Lope de Vega uses monstrosity and grotesque characterisation to mock Conde Enrico's apparently insuperable and irrational fear of marriage. Even more than Julia, Enrico is frightened by matrimony: getting married and especially choosing a wife are to him "materias [...] peligrosas" (v. 24) [dangerous (...) matters] and "un casamiento errado, no es tanta pena morir" (vv. $131 \mathrm{f}$.) [a mistaken marriage is worse than dying]. He is so scared of making the wrong decision and of the consequences this would have for him and his subjects, namely "dishonour" and "infamy" ("[una mala elección] llevaba en su rigor / una noche de su honor / y una infamia de su vida"; vv. 18-20 [(a wrong choice) brought in its hardness / night on his honour / and infamy on his life]). Marriage's indissolubility and the consequent fact that in early modern Catholic Spain there was no remedy for an incompatible,

45 In his later play, The Roaring Girl (1611), written in collaboration with Thomas Middleton, Dekker also portrays a virgin, Moll Cutpurse (based on a historical figure), who does not marry at the end of the comedy, because as Lee Bliss remarks, "like Julia, she wishes to maintain her liberty” (Lee Bliss, “The Renaissance Griselda: A Woman for all Seasons,” Viator 23 [1992], pp. 301343, p. 338, n. 65). This suggests that of the three English playwrights, at least Dekker, despite his adherence to Protestantism, was inclined to understand women who did not wish to get married. 
inappropriate or unbearable spouse help explain why Enrico is paralysed by the idea of finding a wife. Yet his anxiety is depicted as grotesque and so laughable: marriage in Enrico's conceits becomes more frightening than a monstrous creature ("antes entrara / de una tigre en una cueva, / y con fuerza heroica y nueva / de los pechos le quitara / un hijo, o con un león / entrara a hacer desafío [...] o me abrazara desnudo / con las sierpes de Laoconte"; vv. 109-118) [I would rather enter a tiger's cave / and with new and heroic strength / take from her breasts / one of her cubs, or a lion / defy (...) or embrace naked Laocoön's serpents]. Whereas, as a Catholic, Enrico could have legitimately argued, like Julia, that virginity and chastity are preferable to wedlock, it is clearly fear of the unknown, which matrimony represents for him, that stops him: unlike the many monsters he knows, describes and lists, Enrico has no way of making sure the woman he will marry will not feign virtues in order to become his wife and later bring him shame and dishonour.

In addition, Lope enriches the Griselda myth with a new episode which further draws attention to the grotesqueness of Enrico's anxieties: four prisoners are presented to Enrico for him to judge their cases, all of which concern wedlock. As Marie-Françoise Déodat-Kessedjan and Emmanuelle Garnier observe, "Cette séquence [...] fonctionne comme contrepoint comique aux craintes du comte par rapport au mariage" [this episode (...) functions as a comic counterpart to the Conde's marriage fears]. ${ }^{46}$ However, it represents much more than simple "aléas du mariage" [vagaries of marriage], ${ }^{47}$ as these French critiques put it: while all these cases illustrate the worst that could happen in courtship or marriage, the third is so exaggerated that Lope can only have meant it to appear grotesque.

Fabia is the first case: rumour has it that she killed her husband in order to marry her servant, whom she wedded the day after her husband's death. Comically, what troubles the Conde most in the affair is how quickly she was able to choose a new husband and marry him, while Enrico has not been able to take a wife despite contemplating it for years. His questions, during the interrogation, underline his astonishment about how little time Fabia needed to make a decision: “¿En una noche pensaste / un casamiento?”; “¿En una hora una mujer / decreta y busca marido?”; "Pues, ¿cómo yo no me atrevo / y en tantos años no pruebo, / que tú no puedes errar?” (vv. 294 f., 301 f., 304-306; my italics) [Did

\footnotetext{
46 Déodat-Kessedjan and Garnier, "Introduction” to "Lope de Vega: L'exemple pour les femmes mariées et l'épreuve de la patience, 1601 (?),” in: Déodat-Kessedjian, Garnier, Jacqueline Malherbe, Jean-Luc Nardonne, and Yves Peyré, edd., L'Histoire de Griselda, une femme exemplaire dans les littératures européennes, 2 vols. (Toulouse: Presses Universitaires du Mirail, 2001), vol. 2, pp. 127-146, p. 131; my translation.
}

47 Ibid.; my translation. 
you over a night think / of marriage?; In an hour a woman / decides and looks for a husband?; Well, how, while I haven't dared / and for so many years haven't tried, / couldn't you err?]. Fabia, thus, stands as a feminine counterpart to Enrico, ridiculing his incapacity to make any spousal decision: “¿qué ciencia es menester [para casarse]?”(v. 303) [What science is required (to get married)?]. Since the only way out of matrimony that also allows remarriage is the death of one of the spouses, as Enrico observes, she found a hasty solution to anxieties over unhappy married life and wedlock's indissolubility: murder. Yet, in the absence of proof he sets Fabia free.

Ironically, her case also partially foreshadows Enrico's future marriage with Laurencia. Fabia married her servant for his virtue: "FABIA: [...] porque conocía / su virtud" (vv. 289 f.) [FAB.: (...) because I knew / his virtue]. The Conde disapproves of this unbalanced match in terms of social hierarchy: "haciendo / a un siervo infame amistad” (vv. 322 f.) [making / shaming friendship with a servant]. However, like Fabia, Enrico will marry beneath him because Laurencia appears extremely virtuous to him.

The second case is that of Flora and Arnesto. According to Flora, Arnesto promised in front of witnesses that he would marry her, so she agreed to have sexual intercourse with him. But he now refuses to marry her because he claims that she is lying, that he never vowed to marry her and that the witnesses are unreliable.

In the early modern period, as previously mentioned, while the Tridentine decrees insisted on the importance of the freedom of consent in the exchange of vows for a marriage to be valid, the publication of bans was also required three weeks before the actual ceremony, which a priest had to celebrate publicly at the church doors. This public enactment of marriage blessed by a churchman was intended precisely to avoid such clandestine unions as that of Flora and Arnesto, in which it is difficult to determine whether the woman is the victim of an estupro (i.e. "deflowered through violence or after having been seduced by marriage promises") in which the young man only feigned his vows to satisfy his sexual appetite or whether the young lady falsely claims her beloved promised to marry her in order to force him into marriage. Despite the laws of the Council of Trent, the freely exchanged vows, even in absence of a priest, were still deemed essential and in trials often favoured estupro victims who either received a financial compensation for the violation of their honour or earned the right to legalise the clandestine union by having it sanctified by a priest in a church ceremony. ${ }^{48}$

48 See Renato Barahona, Sex Crimes, Honour, and the Law in Early Modern Spain: Vizcaya, 1528-1735 (Toronto: University of Toronto Press, 2003); Jesús Maria Usunáriz, “'Volved ya las 
However, at the time when the play is set, that is, at the end of the twelfth century, a betrothal or desponsatio could be made either per verba de praesenti or per verba de futuro. If it was performed per verba de praesenti, nothing else was required, not even a witness. If it was enacted per verba de futuro, then either some condition needed to be fulfilled (parental consent, for example) or the marriage had to be consummated to become indissoluble. ${ }^{49}$ Such betrothals were considered lawful marriages, called matrimonium in facie Dei, so long as both parties freely agreed to their union. ${ }^{50}$

In the case of Flora and Arnesto, it is impossible to determine who has deceived whom: nothing allows an understanding of who is lying because the witnesses are never brought in to be heard. So either Flora is the victim of an estupro, or Arnesto never consented to marriage; and both are guilty of fornication. Yet from the beginning, Enrico places more blame on Flora than on Arnesto (perhaps because her name evokes that of a famous Roman courtesan) and believes the young man when he casts doubts on the witnesses' legitimacy: “ARNESTO: ¿Qué testigos? Que es probanza / hecha entre deudos y amigos. / ENRICO: De ti tengo confianza" (vv. 349-51) [ARN.: What witnesses? If proof / was made between debtors and friends. / ENR.: I trust you]. Overwhelmed by his marriage anxieties, the Conde identifies with the young man who is forced into wedlock by Flora, just as Enrico is pressured by his subjects to find a wife:

ENR.: [...] Di, Flora, ¿tan fácil cosa

es el casar que aunque a gusto [i.e. aunque justamente] $]^{51}$

riendas, porque no os perdáis': la transformación de los comportamientos morales en la España del XVI,” in: Ignacio Arellano and Usunáriz, edd., El Mundo social y cultural de La Celestina: Actas del Congreso Internacional, Universidad de Navarra, junio 2001 (Madrid: Iberoamericana, 2003), pp. 295-321.

49 In the twelfth century the Bologna school, led by Gratian, decreed that, in addition to the spouses' consent, consummation was indispensable to the validity of a marital union, whereas for the Paris school, whose main thinker was Pierre Lombard, the exchange of vows per verba de praesenti only was sufficient. Toward the end of the twelfth century Pope Alexander III ended the debate and adopted Lombard's doctrine (see "mariage" entry in: Alfred Vacant, Joseph-Eugène Mangenot, and Emile Amann, edd., Dictionnaire de théologie catholique contenant l'exposé des doctrines de la théologie catholique, leurs preuves et leur histoire, 15 vols. [Paris: Librairie Letouzey et Ané, 1927] vol. 9, pt. 2, cols. 2149-2152; and Sokol et al., Shakespeare, Law, and Marriage, pp. 16 f.).

50 Jaime Contreras, El Santo Oficio de la Inquisición de Galicia: poder, sociedad y cultura (Madrid: Akal, 1982), p. 644.

51 Déodat-Kessedjian and Garnier emend the verse into "aunque a gusto," which both in the 1615 and 1615 printed versions reads "aunque gusto." I believe, however, that "gusto" is here another spelling for "justo," either to obtain a richer rhyme with "disgusto," or as a printer's 


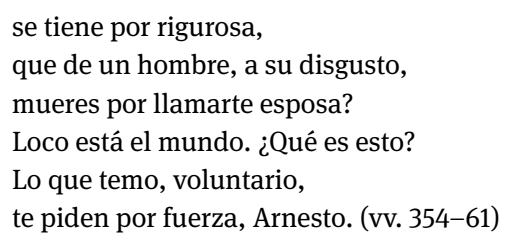

[ENR.: (...) Tell me, Flora, is it such an easy thing / to get married that, although precisely / deemed rigorous, / that by a man, at his displeasure, / you're dying to be called wife? / Mad is the world. What is this? / What I fear, voluntarily, / they ask you by force, Arnesto.]

Then, as Enrico tries to also place some blame on Arnesto for not keeping his alleged promise, the young man appeals to Enrico's desires for freedom and to his marriage anxieties, arguing that, though he committed an offense in forcing himself on her body, she is committing a greater offense in forcing his soul into an unwanted marriage. Enrico is influenced by his projection of his own fears onto Arnesto's case, but at the same time he fights against these anxieties to render justice impartially, which would require either the punishment of both for fornication or that the young man keep his marriage betrothal to repay Flora's dishonour: "ENR.: ¡Qué bien habla en mi temor! / La vela, esperanza, calma, / que navegas en mar de honor" (vv. 381-83) [ENR.: How well he speaks to my fear! / The sail, hope, calm, / That you're sailing in honour's sea].

Enrico finally frees Arnesto and gives Flora a thousand ducats to use as a dowry, treating their case in a similar fashion as early modern Spanish trials for estupro, in which offenders were more often sentenced to provide financial compensation for honour violation than to marry their victims publicly in a church ceremony. ${ }^{52}$ However, the play's setting in the twelfth century would have required that, in a case of estupro, the Conde not only recognise the validity of Flora and Arnesto's marriage, but also that Enrico force Arnesto to behave as Flora's husband and possibly punish him for trying to run away. Justice is, thus, not respected because Enrico's grotesque fears affect his capacity as a judge and make him render immoral sentences.

Finally, Evandro is introduced. His future eighth wife accuses him of having poisoned the first seven. As soon as Enrico hears that Evandro got married seven times, he becomes obsessed with this curious fact, thus obscuring his judgment. The Conde does not care if this man, or rather Bluebeard-like monster, may have killed his seven wives; all Enrico can think of, and marvels at, are Evan-

mistake. "Justo" could be used instead of "justamente" to fit the verse and makes perfect sense in this context.

52 See Barahona, Sex, Crime, Honour, chap. 5, pp. 119-156. 
dro's seven marriages. Not only does the Conde question whether he dreams or is awake, but he repeats the word "siete" ten times at various points in a long monologue in which he compares Evandro to mythical giants such as Atlas, Tityos or Polyphemus, thereby endowing him with monstrous attributes. This catalogue of monsters echoes thematically the previous catalogue of terrifying beasts that Enrico elaborates at the beginning of the play, when he describes his fear of getting married. This indicates that Evandro's seven marriages, even more than the previous two cases, bring the Conde face to face with his anxieties and make him completely lose his mind: Enrico frees Evandro, brushing aside that he may be a serial killer and joking, "Mando que luego un pintor / por monstruo te me retrate / y ponga en el corredor" (vv. 469-71) [I order that later a painter / as a monster draw your portrait for me / and place it in the hall].

While Enrico complains that "loco está el mundo," he does not realise that, actually, his own fears are driving him mad and preventing him from sanely delivering justice. On the one hand, the jail from which these four people emerge functions as a metaphor for the Conde's view of matrimony: a husband or wife who marries the wrong person will live in a mental prison, given marriage's indissolubility. Two of these cases also literally imply that the only escape from marriage is to commit murder, which will lead one into a real jail. However, by setting the four prisoners free, Enrico grants them what he will never allow himself: an exit that puts an end to marriage and prevents it from destroying one's honour. On the other hand, pardoning all these people also indicates that Enrico's fears threaten the good government of his land. Because he is a ruler, the influence of his marital anxieties over his judgment has greater consequences than for other individuals: the entire community and social order are troubled and put at risk by his liberation of potential murderers. As a consequence, these three cases convey the long-established and enduring idea present in Catholic countries that celibacy is not an acceptable way of life for aristocrats: it generates disorder, that is to say, it threatens the bonum communitatis which rulers must preserve and protect.

Moreover, the prisoners, and especially Evandro, illustrate how unusual Enrico is in taking so much time and care in deciding to get married. The Conde's reading of Evandro's seven marriages as a monstrosity reflects in an inverted way the grotesqueness of Enrico's anxieties. These are further proved ridiculous by the fact that he decides rather quickly to marry Laurencia-even more quickly than Fabia's decision to remarry: after only a short conversation with Laurencia during their first meeting, the Conde makes up his mind to take her as his wife.

As I have showed, the Patient Griselda myth is used in both El ejemplo de casadas and Patient Grissil as a basic story line to engage with marital issues, but is enriched in secondary episodes with new characters. Although the Spanish and the English dramatists do not expand the myth with the same episodes or 
same character-types, they do so with the same purpose in mind: to put emphasis on the anxieties marriage raises in those who should get married and in the community around these individuals. Both Lope and the English dramatists decide to address these anxieties with humour and satire in order to exorcise them through laughter. They also use the same rhetorical tools: the monstrous and the grotesque. Dekker, Chettle and Haughton, however, while they ridicule Julia, also acknowledge that her fears may be justified and that celibacy may be a preferable option than wedlock for some. Yet, the seditious and heretical potential of such a statement forces them to be careful and end their play in such a way that Julia will not have the last word and be condemned to hell by the proverb for old maids, which has them lead apes in hell.

Consequently, what these two plays share are: a myth or plot, which can be traced back to late medieval Italy and had acquired European cultural importance by the early modern period; rhetorical devices whose origins can be found in the Greco-Latin tradition, but which were kept alive during the Middle Ages and frequently used for satirical purposes in early modern Europe; and social preoccupations about marriage, rendered more acute in the sixteenth and seventeenth centuries by the debates among Catholics, Protestants, politicians and laymen around this ritual. While this points towards a common European culture and cultural network in which this literary and ideological material circulated or floated, Patient Grissil and El ejemplo de casadas also present traits belonging to their respective national cultures. Patient Griselda is a European myth, but in each of its realisations, it acquires features of the national culture in which it is retold; and the marriage anxieties it helps to address are formulated according to these cultures. For the Protestant English dramatists virginity in opposition to wedlock is still a problematic issue, whereas for Lope the Catholic notion of marriage's absolute indissolubility until one of the spouses' death is a prominent concern. 
